Ideas, 5 th ed., to be issued later this year. The winning entries will be on display at the John Cotton Dana booth at the New Orleans ALA conference.

\section{Things to consider}

This year winners share a common theme. Their programs are not wholly unique in the sense that it was the first time a library had ever brought up an automated system or begun a Friends group. But both entries showed evidence of planning realistic goals, then setting about accomplishing them in in- novative ways. Jon Eldredge, a frequent observer of JCD entrants from academic libraries, delineated the key ingredients of a winner in a 1986 article (CURL News, October 1986, p. 579). Entry packets for next year's contest are available from the Marketing Department at the H. W. Wilson Company, 950 University Avenue, Bronx, NY 10452. Academic libraries have much to gain by promoting their services, then promoting their efforts by applying for a John Cotton Dana Award or Special Award.

\title{
How others see us
}

\author{
by Diane Richards
}

Reference Librarian

North Dakota State University and Paula Elliot

Reference Librarian

Washington State University

\section{Examining the image of the academic librarian.}

$I_{n}$ n common with other professionals, librarians have long been concerned with their image. Our profession has been plagued with an unpleasant, and increasingly irrelevant, librarian stereotype. In an effort to make some headway with this problem, the Washington State Chapter of the Association of College and Research Libraries convened its Spring Meeting in Ellensburg, Washington, on April 22, 1988, for a program entitled, "How Others See Us: The Professional Image of the Librarian."

The topic of this meeting was particularly timely for academic librarians employed in the State of Washington. After several years of minimal pay increases for faculty at state schools, a bill granting substantial raises was introduced in the first session of the 1987-88 Biennial Legislature. Initially, this bill specifically excluded librarians, even though librarians are considered faculty at all the state institutions except the University of Washington, where they are classed as "academic" employees.
In prior years, librarians were grouped with faculty at all the institutions when raises were considered. This time it was different. Because of their more nebulous status and a perception that their university administration was not supportive, the University of Washington librarians decided that some direct action was necessary. Hiring a lobbyist to present their case to the legislature seemed most appropriate. The outcome was to include permissive language in the bill that allowed each institution to decide for itself whether to include librarians as faculty. Ultimately, all the state schools gave their librarians the same access to raises as other faculty.

However, the entire process and its attendant publicity brought to the forefront the question of how librarians are viewed by those outside the profession, particularly when money - and moralehang in the balance.

Against this backdrop the 1988 Spring Meeting took place. The timeliness of the topic; the conve- 


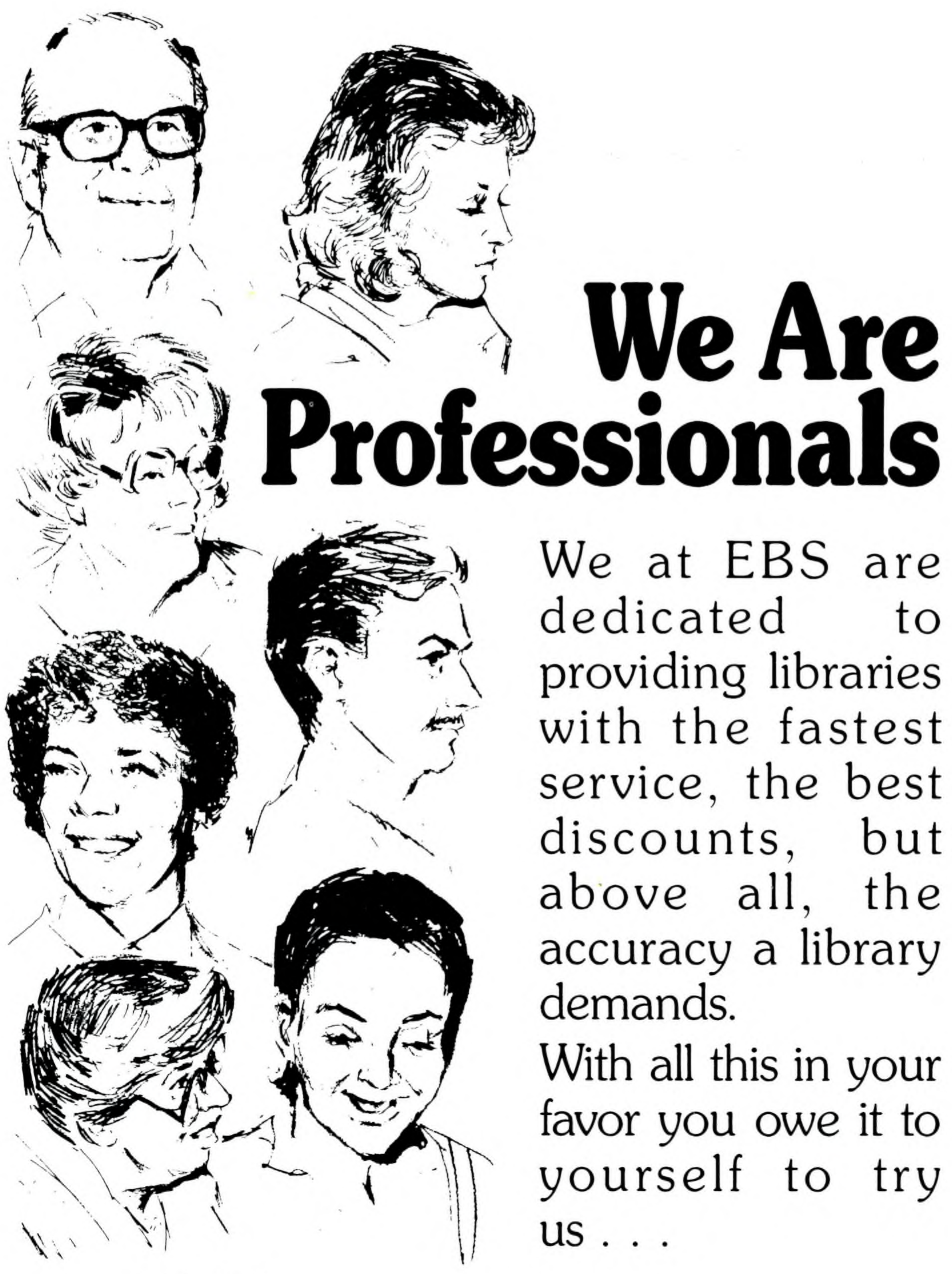

\section{(III) IIII) IIII) \\ E.B.S. BOOK SERVICE THE BEST CHOICE. \\ ESTABLISHED 1949}

E.B.S. INC. BOOK SERVICE - 290 BROADWAY, LYNBROOK, NEW YORK 11563 - 516-593-1207 
nience of the location (Ellensburg is near the center of the state); and the one-day format, making an overnight stay unnecessary, combined to draw a much larger group than usual. The program began with a panel presentation by three invited speakers. Sharon Foster, the lobbyist hired by the University of Washington librarians, spoke on legislative views of the librarian. Robert Smith, vice provost for research and dean of the Graduate School at Washington State University, addressed faculty and administrative perceptions of librarians. Lawrence Bowen, associate professor of communications at the University of $W$ ashington, gave suggestions for improving the librarian's image.

Sharon Foster spoke first and sounded a theme echoed by the other speakers. Librarians, she said, need to decide what image they want to project and unite to achieve that. She noted that the fragmentation of librarians into many organizations, each with its own agenda, is confusing to legislators. Legislators are not hostile to librarians, but they are often ignorant of what librarians do. Educating them is essential. State-employed librarians need to decide what they want from the legislature, develop a specific plan to achieve those ends, and organize long before the legislature is actually in session. Events move too quickly during the sessions for last-minute efforts to be effective. "There is no doubt that the groups who make the most noise are the ones that are heard," she said. She also urged librarians to become active participants in the selection of key state officials, supporting candidates for Governor, Lt. Governor, and Superintendent of Public Instruction who are sympathetic to library concerns.

Robert Smith based many of his remarks on research* done for him by the conference coordinator, Diane Richards, confessing his prior ignorance of the "librarian stereotype." After discussing the literature, he reiterated the theme introduced by Sharon Foster, saying that "librarians should identify a special niche for themselves and pursue it with vigor." He suggested that in moving from an image as "helper" to one as team member or partner, librarians might promote themselves as possessors of unique and specialized knowledge rather than as dispensers of books. He specifically mentioned the role Richards had assumed in relation to this talk as one that is of great value to administrators, who are often called upon to speak on topics outside of their particular discipline. He described this role as "sifting and winnowing references," "placing the literature in perspective," and "serving the need to understand literature that is representative, not exhaustive." He went on to say that the value of this role was such that he would be willing for a librarian to be listed as the first author in a collaborative effort.

*For a bibliography, contact Diane Richards, Reference Librarian, North Dakota State University Library, Fargo, ND 58105.
Lawrence Bowen offered librarians the perspective of a marketing expert, drawing on the principles of his discipline. Following some amusing anecdotes about the marketing campaigns for now-familiar products-campaigns that had radically changed that product's image-he reminded the audience that this kind of change comes slowly. "It takes a planned, coherent, cohesive effort. Implement change gradually. Build to change. For attention, whisper. But whisper clearly, slowly, consistently. It's not what you say; it's how you say it." In concert with the other speakers, he stated, "Define how you want to be perceived. Agree on where you want to be."

Bowen made these additional points about projecting an image:

- Link up with a major transition point; it makes you visible. Capitalize on the excitement that surrounds the new. "Hitch your wagon to a star."

- Put a dollar value on the service you provide. People place less value on service that is free.

When the audience had heard the three presentations, they formed into several small groups to discuss their impressions. In workshop style, recorders reported in a concluding session the reactions of conference attendees. While all three guests offered well-intentioned advice, their remarks also provided personal insight into "how others see us": on the one hand, a fragmented group, with many conflicting concerns; on the other, indispensable and highly valued public servants.

On the implicit assumption that a negative public image is linked to a low salary, there was general agreement that librarians should unite to present a strong, identifiable public image. However, in a profession that has attracted individuals of diverse professional backgrounds, attitudes, and priorities, some felt that the highly valued diversity which has traditionally characterized librarianship would be threatened.

In a chapter largely populated by state employees, concern for the Legislature's actions of a year ago surfaced in the discussion. Many felt that Washington legislators misunderstood the nature of librarians' activity, and, on some campuses, their faculty status. Because not all Washington State institutions consider librarians faculty, there is further confusion about academic librarians' roles. Librarians in private institutions found relevant parallels in their own administrative structures. One astute conference attendee admonished the group, "We have to pursue this one on our own; teaching faculty have their own problems." It was unanimously determined to pursue common concerns.

Although the meeting centered around legislative, faculty, and administrative perceptions of academic librarians, it provided an opportunity to discuss public perceptions of librarians more generally. Certainly the concern for "how others see us" 
is not a new one. The debate over professional image has prevailed in our literature and on our coffee breaks. As a program for the Spring Meeting of the
Washington State Chapter of ACRL, it offered a formal arena for substantive discussion and decision-making.

\title{
A coordinated program for state agricultural publications
}

\author{
By Sarah E. Thomas \\ Chief, Technical Services Division \\ National Agricultural Library
}

\section{A cooperative project of the National Agricultural Library and land-grant university libraries.}

B cations is one of the most challer cations is one of the most challenging tasks facing documentalists and agricultural librarians today. State Agricultural Experiment Station and Extension Service publications contain valuable information on scientific research and practical application of that research which is important for researchers and consumers. Yet, because of the difficulties inherent in tracking and providing access to this literature, the information contained in these publications has been severely underutilized.

Librarians have long recognized that control of state publications is even more elusive than that of federal documents, and they are not used as frequently as federal publications. ${ }^{1}$ Terry Weech, a documents specialist, observed that "state government information sources are often considered secondary in importance to national and international information sources." 2 Yet these publica-

\footnotetext{
${ }^{1}$ David W. Parish, "Some Light on State Bibliographies," Government Publication Review 12 (January-February 1987): 65-70.

${ }^{2}$ Terry I. Weech, "Introduction," Government Publications Review 10 (March-April 1985): 155.
}

tions contain useful information, and there is some evidence that enhancing access, for example, including records for government publications in an online catalog, significantly increases their level of use.

The route to providing access to state agricultural material is fraught with peril at every turn. Acquisition of state agricultural publications can often be a haphazard process, as some agencies responsible for distribution of this literature issue publications in limited numbers, do not automatically include libraries on their mailing lists for distribution, and publish without observing bibliographic conventions with regard to attribution and identification of which series a particular title should be issued in. For the acquisitions librarian, the task of obtaining this often fugitive literature can require great patience, perseverance, and ingenuity.

Once the material has been acquired for the library, serial checkers and catalogers face additional problems. State agencies sometimes drop, consolidate, and rename titles without adequate announcement, making the tracing of their bibliographic history confusing, complicated, or even 